\title{
Media Discourse And Gender: Issues Of Reconstruction Of Gender Ideologies In Pakistani Television Advertisements
}

\author{
Sarwet Rasool \\ Department of English \\ Fatima Jinnah Women University, Rawalpindi
}

\begin{abstract}
Traditionally Pakistani society exhibits stereotypical patriarchal gender ideologies in all spheres of life. Pakistani media also operates under the same patriarchal framework of received definitions of gender. When it comes to Pakistani television advertisements, to ensure social acceptability, typically they represent men and women in their perceived gender roles. However, recently a wave of change can be noticed in these advertisements as many advertisements challenge and/ or reconstruct gender ideologies implicitly or explicitly. In the current research advertisements selected from diverse domains including edibles, cell phones and services, beauty products and toiletries denote a change across gender stereo-typicality. The paper investigates whether, how far and in what ways gender roles and ideologies are challenged and reconstructed; and what thematic, linguistic and extra linguistic strategies are used in Pakistani television advertisements. It is expected that the paper will provide insights into the processes of reconstruction of gender ideologies in Pakistan.
\end{abstract}

$$
\begin{aligned}
& \text { تلخيصِ مقالْ }
\end{aligned}
$$

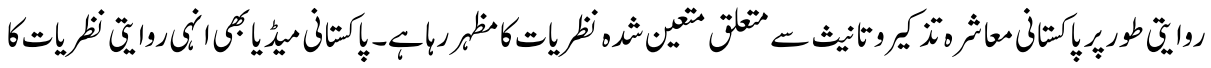

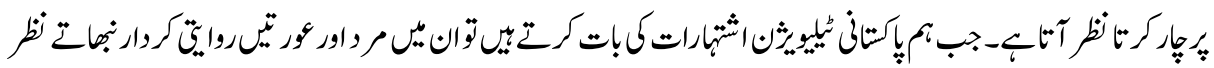

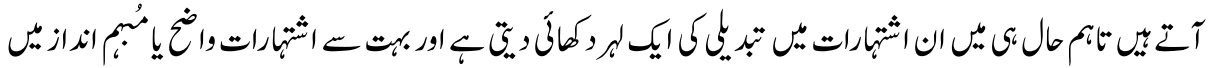

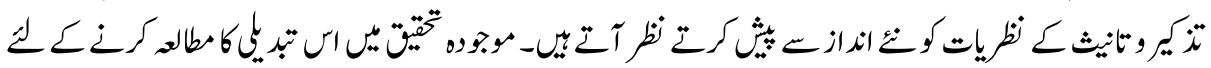

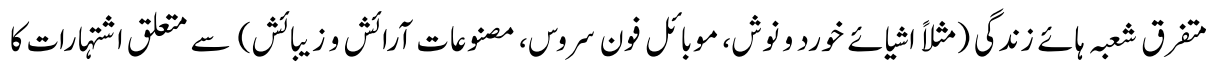

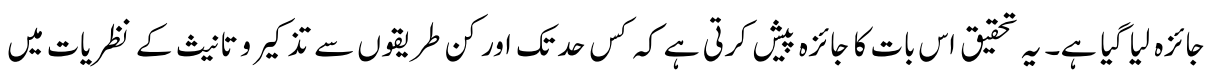

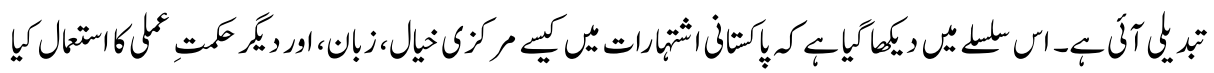

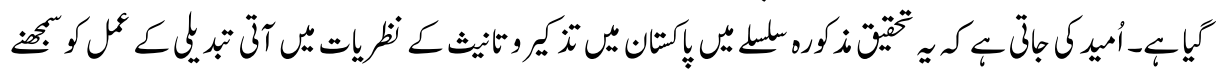

$$
\begin{aligned}
& \text { يس م, كظر،وك- }
\end{aligned}
$$

\section{Introduction}

Pakistani society conventionally stands for pre determined patriarchal norms that display stereotypical patriarchal gender ideologies in all the spheres of life. These perceived gender ideologies often reject giving certain human rights to a particular gender. 
Pakistani electronic media also presents and projects the same impression of this patriarchal framework of received definitions of gender in the social context.

Pakistani media is working under the long established social patterns of thought so it places men and women in their standardized gender roles. However, as a result of globalization, these perceived gender ideologies are being challenged. Fenster (1999: p.10) perceives gender as "a powerful and transformative theme in urban planning in recent years". With the changing times, gender has captivated and grabbed attention of various feminist movements as it emerged a considerable change in women's participation in different walks of life and their role has changed from passive to an active participant.

The current research is focused on the representation and reconstruction of perceived gender identities of ideologies. It examines that how far gender ideologies are reconstructed and are presented and not presented in a progressive way.

\section{What is Gender?}

The notion of gender employs a wide range of stereotypical ideas regarding femininity and masculinity that exist in almost every society. It is very important at the outset to understand the difference between sex and gender which are usually taken as synonyms. Sex differences in human beings can be noticed in terms of "physical distinctions in anatomical, chromosomal, hormonal, and physiological characteristics", whereas "gender refers to the social, psychological, and cultural attributes of masculinity and femininity that are based on the previous biological distinctions" (Tischler, 2004: p.267-268). In the same way O'Shaughnessy and Stadler (2002: p.230) defined this distinction as: "sexual difference is a biological difference between a male and a female," while gender is related to "social and cultural roles, about behavior that is deemed socially acceptable for men and women, and about "masculinity" and "femininity" ". Kessler \& McKenna (1978: p.9) reiterate that sex generally assigns "the biological components of maleness and femaleness"; thus, there are two sexes- male and female- and, consequently, two gendersmasculine and feminine.

The concept of gender deals with the "perceived differences between and ideas about women and men, male and female" and "These differences are socially constructed" Rose (2010: p.2). It defined that gender roles vary from society to society; and men and women have to put on such roles in order to survive in a society. There are certain defined gender roles that are stereotypically presented and are approved of universally. For instance, "in all contemporary societies for which we have statistics, women do most of the cleaning, cooking and sewing, most of the work of looking after children, and almost all of the work of caring for babies" (Connell,2009: p.3). To him this is a cultural definition of women as "caring, gentle, self-sacrificing and industrious, i.e. as good 
mothers"; while "fathers are supposed to be decision-makers and breadwinners, to consume the services provided by women and represent the family in the outside world." Kessler and McKenna (1978: p.1) discuss it by stating, "as we go about our daily lives, we assume that every human being is either a male or a female." According to them, "the cultural trappings of males and females have varied over place and time, but that nevertheless, there is something essentially male and something essentially female. It is a fact that someone is a man or woman, just as it is a fact that the result of a coin toss is either heads or tails, we can easily decide the case by looking."

\section{Defining Gender roles and Ideologies}

The cultural beliefs, norms and values of a society are termed as the ideology of a society. According to Croteau and Hoynes (2000: p.157), "an ideology is basically a system of meaning that helps defined and explained the world and that makes value judgments about the world it refers not only to the beliefs held about the world, but also to the basic ways in which the world is defined". Croteau and Hoynes (2004: p.79) further illustrate, "people's consciousness of who they are, of how they relate to the rest of the society, and therefore of the sense they make of their social experience is produced by society, not by nature or biology." While Kessler and McKenna (1978: p.8) add to this concept by stating that gender identity means "an individual's own feeling of whether she or he is a woman or a man, or a girl or a boy. In essence gender identity is self-attribution of gender."

According to Kessler and McKenna (1978: p.11), a role is "a set of prescriptions and pro scriptions for behavior-expectations about what behaviors are appropriate for a person holding a particular position within a particular social context". Therefore, a gender role, is a set of expectations about behaviors, and about do's and don'ts deemed appropriate for a particular gender by the society. According to them, "the obligatory nature of gender roles is so firm that when dictionaries attempt to define woman and man, they often do so by listing gender role behaviors. ["Man: one possessing a high degree of...courage, strength, and vigor" Webster's 1973, p.889]".

Ralhan and Lambat (2007: p.135-140) give some examples such as "Daddy's little girl", or "Mommy's big boy", "Did you ever see your father cry?" which are all about gender ideologies. While defining the stereotyped female role, Kessler and McKenna (1978: p.12) illustrate them as "low-valued behaviors and traits as passivity and helplessness". Hermes (2007: p.195) terms the headscarf, the miniskirt, the suit or the cowboy boots as gendered identities. These are the stereotypical gender identities that are deeply embedded on subconscious level in people living in patriarchal or gender based societies.

\section{Defining Patriarchy}

Patriarchy literally means 'rule by fathers'. A patriarchal society is one in which the society is controlled by men and the head of the family is male who controls all family matters. Cambridge Advanced Learner's Dictionary (2008: p.1042) defined patriarchy as "a society in which the oldest male is the leader of the family, or a society controlled by men in which they use their power to their own advantage". Goldstein (2001: p.2) defines 
patriarchy, masculinity and femininity in relation to each other. To him "Patriarchy mean(s) social organization based on men's control of power. Masculinism (ist) refers to an ideology justifying, promoting, or advocating male domination. Feminism...opposes male superiority, and promotes women's interests and gender equality". In short patriarchy is a social system in which much of the power rests in the hands of male members, who dominates all spheres of private and public life.

In this regard O'Shaughnessy and Stadler asserted:

Patriarchy is a system based on the 'law of the father'. These are two ways: first, through lineage (children tend to take on their father's family name rather than their mother's); second, through the legal and political institutions that, although no longer given over into the exclusive power of men, have developed as male institutions. In the past women could not hold political office; they were excluded from voting rights ( women won the right to vote only after protracted struggle) ; they had lesser legal rights; and married women were regarded as the property of their husbands.

(2002: p.238)

Gender parity implies the right for human parity. It is the right of equality irrespective of being a man or a woman, especially in terms of power.

\section{Human Rights}

According to Griffin (2008: p.9) the "use of the term 'human rights' began at the end of the eighteenth century (for example, in the French Declaration of the Rights of Man and of the Citizen (1789)- 'les droits de l'homme'), but it gained wide currency only in the middle of the twentieth century. Before the end of the eighteenth century, the talk was instead of 'natural rights' ". In the context of human rights, Orend (2002: p.15) asserts that a right-holder is one "who has the right in question," and the main distinctive element behind the idea of human rights is the belief that "all human beings have, or hold, human rights". He (2002: p.17) gives the definition of rights by the Oxford English Dictionary (OED) according to which 'right' is:

1. "That which is morally or socially correct or just; fair treatment."

2. "A justification or fair claim."

3. "A thing one may legally or morally claim; the state of being entitled to a privilege or immunity or authority to act."

Donnelly (2003. p.10) considers human rights as "equal rights: one either is or is not a human being, and therefore has the same human rights as everyone else (or none at all)". He (2003: p.11) views human rights differently as "not just abstract values such as liberty, equality, and security", rather as "rights, particular social practices to realize 
those values". According to him, "human rights are "needed" not for life but for a life of dignity". Arat (2000.p.69) talks about the situation of Muslim women in the light of the international human rights and states "among all women, the ordeal of Muslim women has been most challenging and is frequently addressed not only by human rights advocates and feminists, both within and outside Muslim-populated countries, but also by the Orientalist critics of Islamic culture and states".

\section{Construction and Reconstruction of Ideologies}

All ideologies including gender and patriarchal ideologies constructed and reconstructed through various channels. O' Shaughnessy and Stadler (2005: p.215) refer to Althusser (1977: p.133-48) who was interested in "how ideology was transmitted socially, how it was that people took and accepted the values of the dominant groups even if these views might not be in everyone's interests". He proposed two sets of mechanisms that are involved in achieving this. These are Repressive State Apparatus (RSAs) and Ideological State Apparatuses (ISAs):

- RSAs are mechanisms that are called into play to force people to conform to the dominant ideology.

- ISAs do not force people; they work more like hypnosis, convincing people or winning their consent to the dominant ideology. Althusser again identified key institutions that carry out this socialization process: the Church, the family, the education system, and the media.

(O’ Shaughnessy and Stadler, 2005: p.215)

The current research is based on media; and the selected television advertisements are analyzed to observe how dominant ideologies are (re)presented, transferred and reconstructed in order to achieve certain purposes.

\section{Representation of Gender Ideologies in Media}

According to Buckingham and Bragg (2004: p.71), "media are the sources through which boys and girls construct their identities". Lemish (2010: p.8) further adds, "media representations are contemporary expressions of deeper ideological assumptions and discourses rooted in worldviews and belief systems that produce a particular view of gender". Media plays its role in representing gender ideologies "by informing us and entertaining us" Hermes (2007: p.194); and the media both implicitly as well as explicitly teach us about appropriate gendered behaviour including how to resist and challenge gendered codes. 
Fairclough (1995: p.103) throws light on a very significant fact about media as he says, "media texts do not merely "mirror realities" as is sometimes naively assumed; they constitute versions of reality in ways which depend on the social positions and interests and objectives of those who produce them". O'Shaughnessy and Stadler (2002: p.22) put forward a very interesting definition of gender representation as "gender is a construction not material", thus "gender representations in the media representations of representations" whereas to Fairclough (1995: p.103) representation of gender ideologies "takes place through themes, actions, language and extra-linguistic features". As an example, Fairclough quotes Croteau and Hoynes (2000) who reported that "females are generally shown in media with their full bodies featured whereas male close-ups are only of their faces". Fairclough further quotes Krolokke \& Soreson (2006) who stated, "the camera is male-dominated and for that reason men and women are presented as active and passive respectively". In this regard, Buckingham and Bragg (2004: p.71) conclusively illustrates, "it is in and through the very practices of media consumption and the positioning and identifications they solicit-that gender identities are recursively shaped, while those practices themselves undergo a process of gendering along the way."

\section{Advertisements: Challenging and/ or Reconstructing Gender Ideologies}

Advertisements play a vital role in molding thinking patterns and beliefs of the viewers and leave long lasting impressions on them. Chafai (2007: p.27), in this respect, opines, "people are exposed to the advertising process wherever they are" and considers advertising as "an 'ideal tool' for reaching people economically, but it is a device of attaining and maintaining contact with persons socially, culturally, politically and even psychologically".

Discussing the semiotic aspect of advertising, Chafai (2007: p.28) asserts, "through images, verbal language or symbols, consumers come to identify themselves with the merits and significance of the advertised product in their everyday life". To him, "advertising has to know the world of consumers, their sense of identity, their attitudes and expectations and then create associations between people's dreams and the commodity" as consumers deduce meaning not only from the product itself but also from the world they live in, from their everyday experiences, and from their set of beliefs and values that provide the suggestive meaning of the product (2007: p.32, 33). As far as visual images in advertising are concerned they attempt to establish a relation between the commodity and socio-cultural characteristics and attributes. Kellner (1995: p.127) asserts that the role of images is not only limited to the reinforcement of the idea of selling a product, rather they have a vital role in selling a "worldview, a lifestyle, and value system". Messaris (1997: p. vii) illustrates three major functions of visual images as "they can elicit emotions by stimulating the appearance of a real person or object; they can serve as photographic proof that something really did happen; and they can establish 
an implicit link between the thing that is being sold and some other image". On the other hand, Fowles (1996: p.149) explains that the use of images in advertisements by stating that the role of images in advertising is "to display a 'human context' which derives meanings from the product, and it is for such a reason that the majority, if not all advertisements, contain images of persons, especially young people". In fact advertising "mirrors the routine of everyday life, and attempts to create original meanings" (Chafai, 2007: p.37).

Discussing the domain of advertising, Barthel states:

Advertising is about appearances. It is also about information, but what interests us, what excites us in and about advertising is how objects, or products, become ideas, how they become gifted with appearances: how they make appearances and help us make appearances. This does not happen through magic. It happens through the advertisers' skill at positioning the product, creating an image, "finding a place for it to live in our minds". Information becomes part of appearance.

(1988: p.1)

Analyzing gender representation through the spectacles of feminists, Barthel (1988: p.9) further illustrates, "feminists have been much concerned about the importance of appearances, particularly within women's lives" and according to many feminist writers reaction of people towards a woman is largely determined by how she presents herself.

\section{Selection of Data for the Current Research}

As this research is based on media, selected television advertisements from diversified domains of life are analyzed to observe how dominant ideologies are transferred and reconstructed to achieve certain purposes. For the current research advertisements are selected from the domains of edibles, cell phones and services, beauty products and toiletries. The medium of television is selected as it is one of the most popular and watched media; and particularly television advertisements are selected because they are repeated frequently so leave lasting impressions on the minds of the viewers. The data is collected from Pakistani television advertisements which are telecasted from Pakistani channels: private and public. After selecting the advertisements they are downloaded from www.youtube.com. As the viewers do not know the particular timing when a specific advertisement will be on-air so it is not possible to record them from television.

\section{Duration of Data Collection}

All the selected advertisements were on-air during 2010- 2011. 


\section{Research Question}

Whether, how far and in what ways gender roles and ideologies are challenged and reconstructed in the Pakistani advertisements; and what thematic, linguistic and extra linguistic strategies are used in this regard? The research also investigates that how these beauty advertisements exhibit and/or manipulate issues of gender and power relationship through linguistic and extra linguistic choices.

\section{Significance of the Research}

It is expected that the paper will provide insights into the processes of construction and reconstruction of gender ideologies in Pakistan as projected through media.

\section{Presentation and Analysis of Data}

The data is presented and analyzed domain -wise for the convenience of the readers; and is given as follows:

\section{Data Presentation and Analysis of Domain 1 (Edibles)}

The first selected domain is of edibles. Food is one of the basic necessities of life and eating healthy and good food is a desire of almost every human being. In the history of Indo Pak, food has always been a great focus of interest. Pakistanis are fond of eating therefore not only newer variety of food items come into the market everyday but also for their selling purpose, new ads are made for different food items. In this domain, two advertisements - a cooking oil and variety of biscuits are selected.

In both the ads traditional gender roles and relatively new/ progressive roles are interplayed with. We will start with the analysis of ad 1(Pure Cooking Oil) from the domain of edibles.

\section{Data Presentation and Analysis of Domain 1 (Edibles): Advertisement No. 1}

Ad $1^{2}$ selected from this domain is of cooking oil which is a basic ingredient of oriental cuisine. The ad consists of two female characters and four supportive characters: two males and two children. The ad starts with a girl talking to her sister-in law who is cooking food, about the permission from her father to go on a foreign scholarship. The sister-in-law makes disappointing statements claiming that it is impossible because the father would not allow her to go abroad for a year, which makes the girl sad. The children (in the roles of a nephew and a niece) declared that she will be on a hunger strike. In the end, the tension is resolved when the whole family including two males (the brother and 
the father) sits on the dining table. It is shown that due to the positive impact of the delicious food made by the product which her sister-in-law has used for cooking, the father is pleased and gives the passport and the ticket to the protagonist as a token of permission to go abroad.

As far as representation of gender roles in this ad is concerned, we need to notice that the main issue that is introduced in the ad is of the female protagonist's scholarship for which she wants permission from her father. Pakistani societal values and gender ideologies exhibit fixed notions of a typical patriarchal society. Here, a girl wants to go abroad alone which is not common in traditional Pakistani society based on conventional ideas about the roles of men and women. However, as she manages to get permission, it shows the rapidly changing customary values and ideas which are also influenced by media. On the surface level the ad seems to be progressive in nature as it challenges the received definition of gender according to which women are considered to be safe only if they are confined to their homes. On a conscious note, this ad voices the rights for women to get equal opportunities of education; and advocates the idea of an educated independent woman.

Tanaka states, "Semiotic approaches are based on the assumption that communication is achieved by decoding and encoding a message". The semiotic analysis of ad 1 provides multiple meanings. Leung (2010: p.418) states that the language of advertising tends to be "creative, complex, and attention grabbing" and for this purpose, advertisement is presented with various striking elements as "repetition, strategic order, neologisms, superlatives, hyperbole and other creative non-standard use of Advertising language". Leung further states that as an advertisement is tight with a "fixed set of restrictions legal matters and other what is deemed as more trivial issues such as space" (p.418); so, on lexical level the language of advertising has to be very consciously and carefully designed and combined with the visual images with the intention to manipulate what message is to be conveyed to the consumers. To him, for this reason the language of advertising is a "restricted genre" (p.418). The total duration of ad 1 is just 50 seconds, however, the images, language and gestures are crafted carefully to work together to cumulatively produce an effective ad to grab the attention of viewers.

As far as ad 1 is concerned, it is important to notice that to present radical ideas and to get them accepted by a conservative society is a challenging task for the ad makers. To meet the challenge successfully, the progressive and radical idea is embedded in a patriarchal semiotic setting. The sister in law, dressed in a traditional Pakistani shalwar kameez is shown to be busy in the kitchen while a man, probably her husband, in a Western casual dressing is shown to be sitting in the lounge, which is again the representation of typical gender perceptions in our context. 
In patriarchal societies such as in Pakistan, the senior male family member is considered to be head of the family controlling all important household matters; and female family members act under the supervision. In this ad, the role of the girl is progressive as she is going abroad alone for studies, but she is shown to be traditional and submissive in terms of her relationship with her father. At the very outset of the ad the girl enters the room and says:

- Bhabi! Scholarship confirmed. Papa maney?

(Translation: Sister in Law! Scholarship confirmed. Has Papa agreed?)

The statement shows that though the girl is happy about getting the scholarship, she is concerned about her father's permission. In response to her query the sister-in-law says:

- Aik saal baahir akaylay rehna; papa nuhin maanein gaey

(Translation: To live abroad alone for a year; papa won't agree)

In the end when the father says "dekh lena saal se zyada na lage tumhare hath bhe tau peele karne hein" (Translation: Take care that it does not take more than a year; we have to get you married.), it once again reinforces the perceived gender role of a women whose ultimate destination is to get married, having children and doing household chores. In order to make the ad socially acceptable, the ad producer has inserted this statement in the end to reduce the intensity of previously given new and challenging idea of a woman going abroad alone for studies. The physical action of the father, with hands on the heads of both the females (the protagonist and the sister-in-law) further adds to the patriarchal connotations of the ad.

\section{Data Presentation and Analysis of Domain 1 (Edibles): Advertisement No. 2}

Sterk and Knoppers (2009: p.3) asserted, "discourses become dominant and seen as 'truth' as they are repeated across media, over time, amongst people, and as certain social groups benefit from them". Likewise, advertisements are repeated frequently on television in order to capture and influence the viewers. As far as ad 2 selected from the domain of edibles is concerned, it is of a variety of biscuits of different brands.

This ad has a young female protagonist who is going to get married soon. The other character is of the mother-in-law, whose presence is only through a continuous voice over dialogue. The girl who is busy in shopping for her wedding is shown constantly facing objections and restrictions posed by her mother-in-law such as in the choice of her wedding dress, shoes etc. The mother-in-law rejects all the choices of the protagonist by giving arguments based on the gender stereotypical role of a female who should look smart, beautiful, younger and not taller than her groom on the day of wedding. For instance:

- Itni onchi heel!!dulha se lambi lago ge

(Translation: Such a high heel! You would look taller than the groom.) 
The protagonist, who is afraid of putting on weight and looking older than her groom, can not resist TUC biscuits (an advertised product) and satisfies her hunger during shopping with these biscuits because they have fewer calories. The ad plays around the perceived gender ideologies. Usually in traditional patriarchal societies, it is expected from girls and women to be submissive in their attitude and they are not expected to speak for their rights. Most of the times they do not have the right to choose a spouse. When it comes to the arrangements of marriage, they are not expected to be very vocal regarding choices and preparations ranging from the selection of dresses, to dowry to the ceremony itself. In the ad, a girl is shown as getting directions from her mother-in-law who strictly prohibits her of doing certain things. The girl acts upon what she is directed to do. However, as the advertisement progresses we see that when it comes to eating during shopping she speaks up:

- Tau bhook he ghussa nahi ke pi jaon

(Translation: So, it is hunger, not anger that I would suppress.)

The utterance suggests progressive image of the protagonist. Generally it is assumed that women would not show their anger and would suppress their feelings but the ad challenges this traditional idea of femininity and treats the woman as a human giving the right to show her natural feelings. Traditionally women are assumed to be careful about their eating habits in order to maintain good figure. In our society, eating much on a female's part is not appreciated much. But the ad constructs new a female gender ideology by introducing a female who can speak for her rights.

As far as the semiotic or extra linguistic aspects of the ad are concerned, the facial expressions and gestures of the girl show her disliking for the orders of her mother-in-law; she seems to be somewhat aggressive. The ad challenges the set conventional and long established ideas of a submissive and passive female by introducing the new image of a woman who is confident, bold and can speak for herself. The visual depiction of facial expressions of the girl is given in Fig. 3 \& Fig. 4:

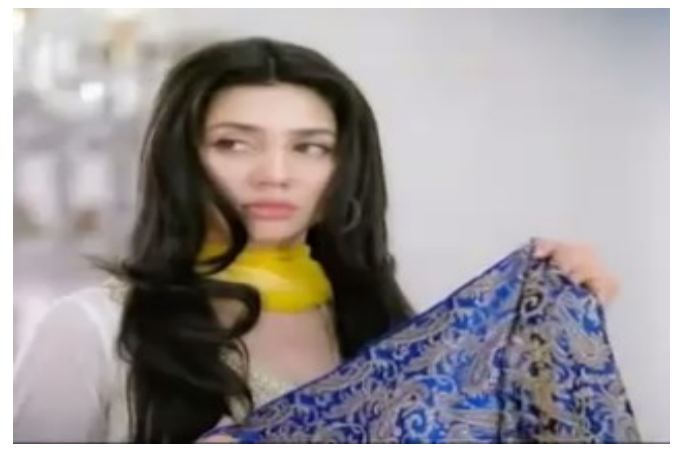

Fig. 3

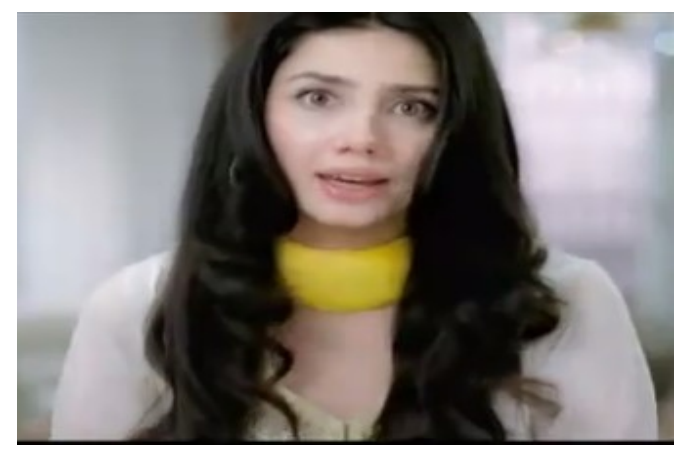

Fig. 4

The discourse of the ad is a fine example of the tension between the old and the new thinking patterns and gender ideologies. However, what needs to be noticed is that the 
protagonist who is apparently presented in a progressive role and who challenges the idea that she should control her hunger, finally decides to eat (advertised) biscuit that are termed as 'hlkay phulkay' (light), which implies that she is concerned about her stereotypical figure and wants to stick to the stereotypical image of a bride who looks beautiful, slim and smart.

\section{Data Presentation and Analysis of Domain 2 (Cell phones and Services)}

From the domain of cell phones and mobile network services two ads are selected.

\section{Data Presentation and Analysis of Advertisement No. 3}

Ad 3 is taken from the domain of cell phones and services. It is about a mobile network and service in Pakistan. This ad has an adult male (father), a child (son), and an adult female (mother) as characters. The situation as presented in the ad is that the wife is sick so the husband and the son are for the first time preparing breakfast to give her a surprise. However, the husband is shown to be incapable of doing kitchen work therefore his son suggests that they can call different relatives in order to have proper instructions about the preparation of breakfast. With the help of these instructions they successfully prepare the breakfast. It is shown that with the help of the mobile network service of Telenor, the man is successfully able to call on different networks and contact different relatives to seek guidance for preparing the breakfast.

The main issue around which the ad revolves is of preparing food which is usually considered to be a female chore in the Pakistani context. As traditionally assigned gender roles expect women to do household work while men to be responsible for outside work, media also generally depicts the same stereotypes. However, the ad appears to be progressive: the male is shown to be working in the kitchen and preparing breakfast for the wife. To win acceptability for this reconstruction of gender role the advertisement maker has designed the discourse very carefully. We need to notice that it is only for ' $a a j$ ' (today) that he is preparing breakfast since the wife is unwell and it is unavoidable. It is interesting to note that on one hand, the ad is bold enough to challenge and reconstruct gender ideologies which are hard for the public to accept. On the other hand, they are conscious and apprehensive about challenging the existing stereotypes of a patriarchal society so they have wrapped these ideas in the same old and traditional notions. Similarly, in this ad, women's domestic work is subtly acknowledged but then is masked behind a progressive idea.

In Pakistan, the segregation of work is performed under perceived gender roles. The expectancy to see women and men in their defined roles is exhibited at the outset of the ad when the child finds the father in the kitchen and asks:

- Papa! Mama kahan hein?

(Translation: Papa! Where is Mama?) 
This statement puts women in the traditional framework of performing perceived gendered tasks. The child asks about his mother as he is not expecting his father to be involved in kitchen chores; the rattling and breaking sound of the utensils and the male's incapability to handle the kitchen chores further emphasize that he is doing such work for the first time. The father reinforces the same idea as he responds: "Mama thori bemar hein..aaj hum dono un ke lie nashta banaen?" However, interestingly, near the end of the ad women's domestic labor is displaced by the fact that she is shown being served...thus drawing attention away from the fact that before this and even later on she is the one who is a constant service provider.

Moving further, there is again a reference to stereotypical female gender functionality that tames the progressive impact of the ad down. All the relatives that are called by the male protagonist for seeking advice about the preparation of the breakfast are females (See Fig. 7 for the snap-shot taken from the ad). There are references to 'nano', 'chachi' and "phopho", who typically and traditionally perform the kitchen chores. This stereotypically is so conformed traditionally that it is automatically transferred from one generation to another.

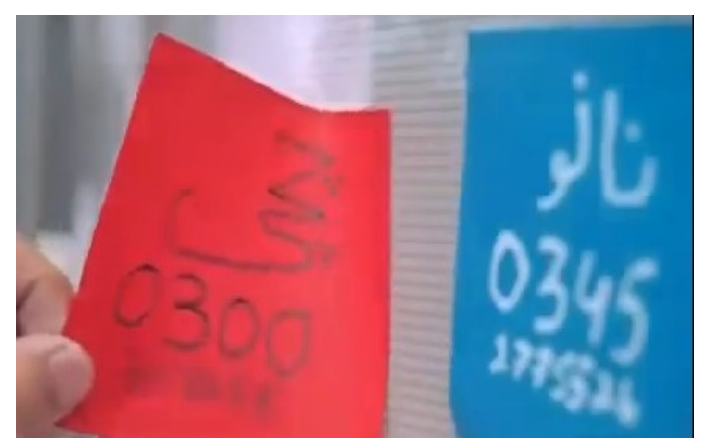

Fig. 7

In this ad, women's domestic labour is displaced. By combining two different discourses or voices about masculinity and femininity, the ad shows an ideological move forward in terms of the male's role but at the same time by drawing attention away from the fact that later on the female has to face the reality of domestic drudgery in traditional gender relations, it conforms to the traditional patriarchal patterns. There is a tension between the discourse of romance/pleasure and the reality of domestic drudgery in traditional gender relations. On the other hand, however, the ad indirectly acknowledges that the whole burden of household work is placed on women as they are supposed and expected to do such things as their duty. Thus the ad is a wonderful example of ideological work.

The humorous element in the discourse undercuts the harsh reality of a dull and boring lifestyle of a woman of doing same chores daily. In the end of this ad when the wife is presented with the breakfast, she humorously says: 
- Hmm nashta tau ho gya. lunch kaun banae ga?

(Translation: Hmm breakfast is done. Who will make the lunch?)

The undertone of the utterance suggests that she is very well aware of the fact that in routine she, not her husband, has to perform such tasks. On the other hand, the husband also takes it in a humorous way as he also knows that he is not supposed to do such chores on regular basis. The expressions of surprise on the face of the wife as the husband serves breakfast also confirm that she was not expecting that.

\section{Data Presentation and Analysis of Advertisement No. 4}

Ad 4 is of about another network which is one of the popular mobile networks in Pakistan. The ad is made on funny notes in which the main male character seems to be annoyed with his wife but when he tries to threaten his wife that he would do a second marriage, he is thrown out of the window by her. The ad ends on a humorous note that changing from your existing network is easy in comparison to a change in your familial life i.e. second marriage.

The ideology of patriarchy and traditional gender roles are challenged in certain ways in this ad. In the ad the man threatens his wife:

- Begum mein dosri shadi kar raha hun

(Mrs. I am doing second marriage.)

In the traditional patriarchal Pakistani context it is a very common threat given to wives in order to make them subservient, obedient and submissive. However, the reaction of his wife to this threat is quite uncommon and opposite to what is expected from a woman in a patriarchal society. She throws the husband out of the window. The ad introduces the viewers to a new image of a woman who displays power and aggression which is not expected from a woman in a patriarchal society. However, the element of humor is used as a tool to subvert the threatening impact of this new idea. In fact the humor reinforces that a woman CAN NOT and IS NOT supposed to do this in a real life situation.

Through the careful choice of language and images working together a humorous situation is created, and the ad subtly acknowledges as well as challenges the gendered identities that are socially created and are deeply embedded into the ways men and women act in their social setups. In the ad, the woman's facial expressions throughout the ad remain stiff, sarcastic and aggressive (See Figs. 8-11). 


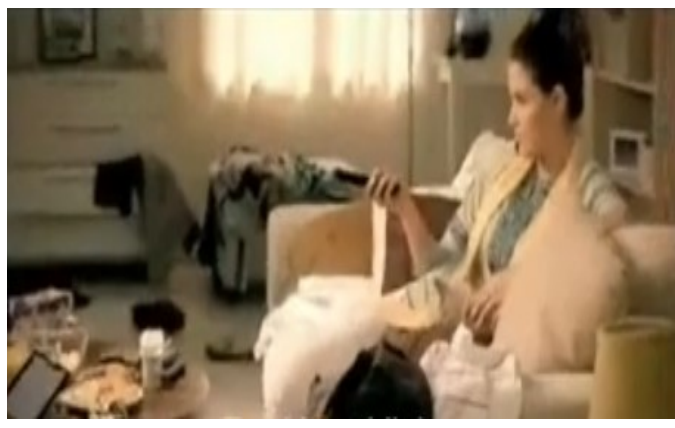

Fig. 8

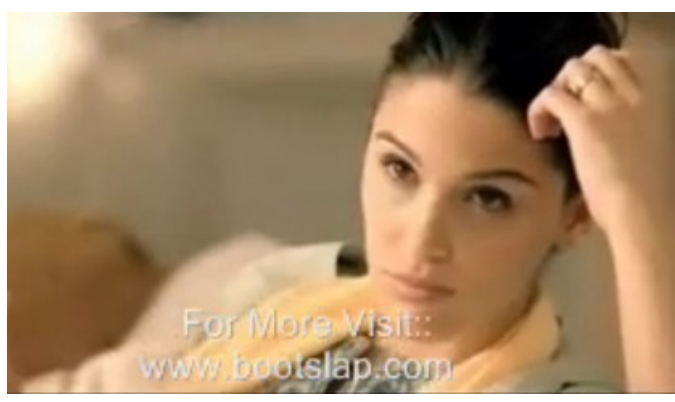

Fig. 10

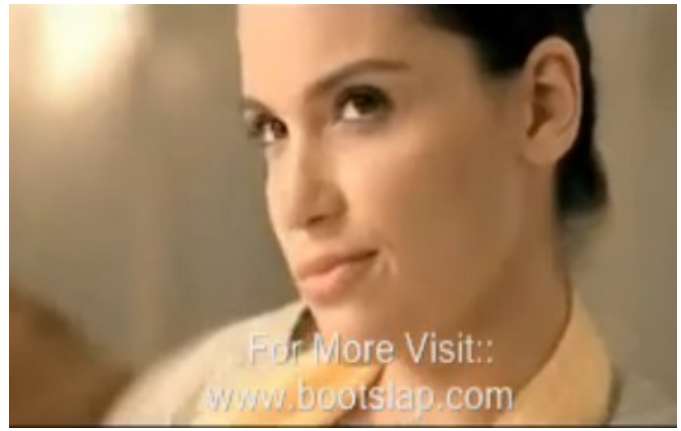

Fig. 9

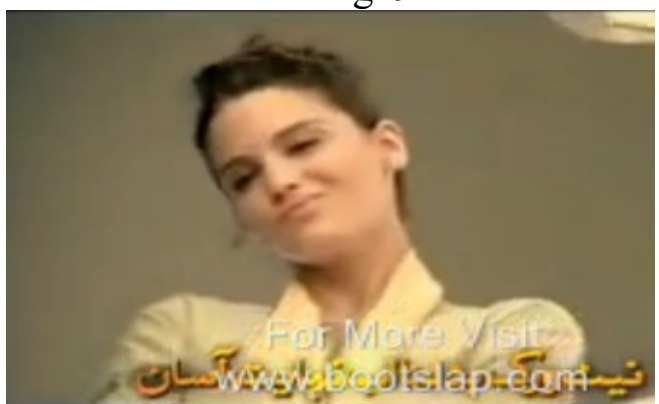

Fig. 11

The ad completely challenging that it perceived concept of femininity as in it, the girl is shown in a complete relaxing mood and watching television while the house is dirty and the kitchen is filled with unclean utensils. When the husband threatens her with the announcement of second marriage, he is shown to be thrown from the window onto the street. What is important to note is that the mood of the woman is used to create humor in the ad. It employs that on a serious note women are not to be so powerful and dominant. Though the ad explicitly contradicts and challenges the conventional ideological images of femininity and masculinity and in a way reconstructs them, in order to make the ad socially acceptable, all these ideas are presented in a humorous manner, and exaggeration is used as a tool. Even in the end of the ad the husband is shown (Fig. 12) cleaning with a broom which is traditionally not expected from males but when shown and seen through the lens of humor these exaggerated gestures and funny expressions become acceptable.

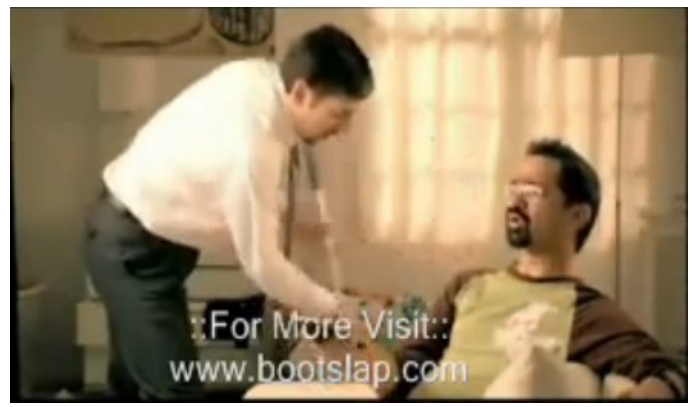

Fig. 12 


\section{Data Presentation and Analysis of Domain 3 (Beauty products and toiletries)}

Two ads, both of a fairness cream product (Skin whitening cream), are selected from this domain (See Figs. 13 \& 14). In the domain of beauty products and toiletries, the selected ads are those which are designed for women. According to O' Shaughnessy and Stadler (2005: p.216), media explains "how we should think, act, and feel". Therefore, "to win support for the dominant ideology through media products, the media must win the support of subordinate and minority groups in society (women, indigenous people, the working class, and so on)". These ads are designed in such a way that they not only grab the attention of the viewers but also in subtle manner present new ideas.

We will carry out the analysis of these ads one by one.

\section{Data Presentation and Analysis of Advertisement No. 5}

Ad 5 is about a fairness cream. There are three female characters in the ad. The ad is about the problem of dark complexion which is a common concern of females in South Asian countries. Pakistani women also use a variety of fairness products which claim to bring fairer complexion in a few days.

The ad starts with a girl coming in rain with umbrella to give lunch to her mother who is a make up artist (See Fig. 15).

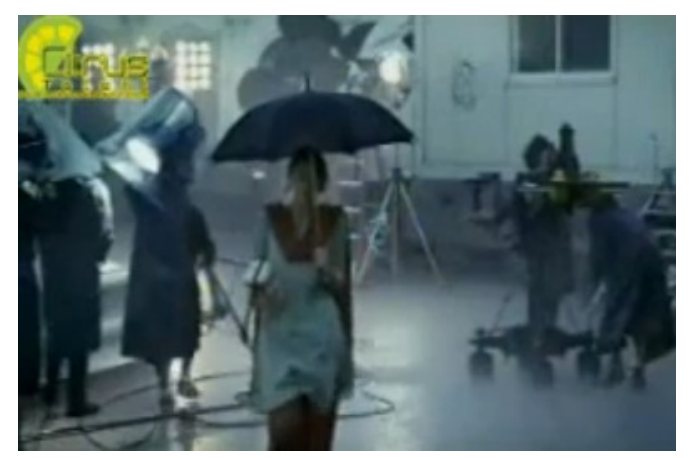

Fig. 15

She suddenly stops and notices that an actress rebuffs her mother as she is not satisfied with her make up. Both, the mother and the daughter feel dishonored. In the next scene, the daughter is shown to be angry on her mother for making others beautiful except her daughter. She asks her mother to make her a star. At that, the mother suggests her to use the product 'fairness cream' for natural beauty. By using the product, the girl becomes beautiful and soon emerges as a superstar actress and gets the award of best actress of the 
year. After receiving the award, she acknowledges her long lasting relation with her mother.

The ad is progressive as the girl is shown to be self confident, moving forward in life without any help of men. She wants to become a superstar and get success in this field that is difficult for a woman in a male dominant society like Pakistan. The ad is also a depiction of gradually changing thinking patterns in our society in terms of perceived gender roles. The girl belonging to a lower/ middle class social stratum wants to become a television actress that is not considered good for women in our society. However, the ad shows that she is encouraged by her mother. To present this idea in a Pakistani advertisement without annoying the viewers who are also a part of the same society and are tuned to the old established ideas, could have been challenging for the advertisement maker but in this ad it becomes acceptable because although the ad challenges the typical gender role of a woman as she is shown to pursue a progressive profession and becomes successful; however, this achievement is subtly linked with her beauty and looks which is a typical emblem of femininity. It is shown that only if she uses the product (fairness cream) she will get success in her career.

In terms of long established gender ideologies, we also need to notice that the girl is judged by a panel of experts that consists of two men and only one woman. Again the camera focuses only on the approving nods of the men. Similarly, immediately after she becomes an actress, in the next scene a male hand gesture is shown as a sign of approval which reinforces the idea of male domination (See Figs. 16\&17):

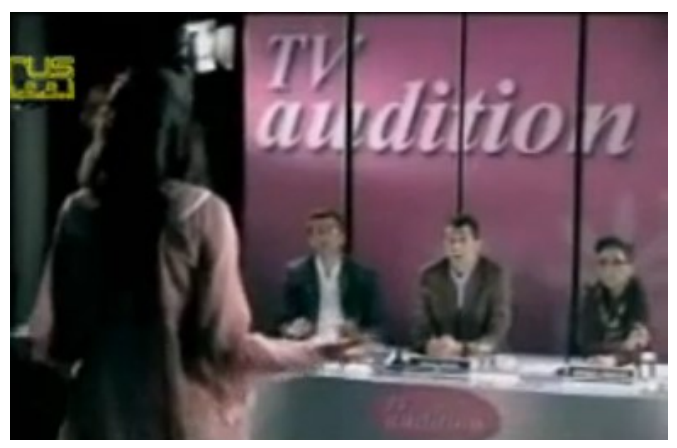

Fig. 16

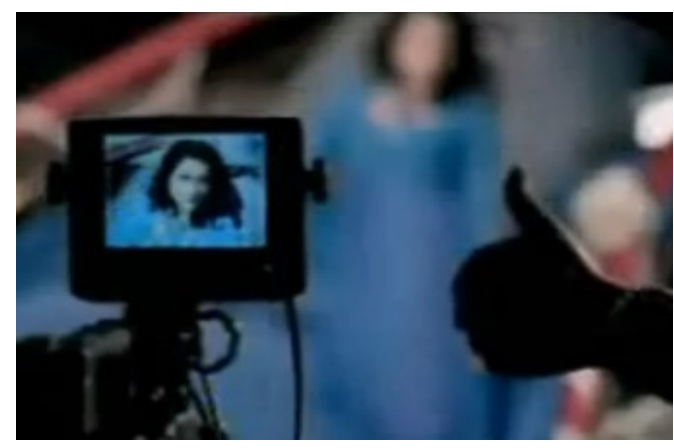

Fig. 17 


\section{Data Presentation and Analysis of Advertisement No. 6}

Ad 6 is also from the domain of beauty products and toiletries, and is of the same fairness cream. The ad offers aspects of a progressive discourse about gender (women) but then incorporates these back into a traditional view of feminine role and ideal femininity.

In this ad, a female character is presented who has dark complexion. The girl is shown passionate about becoming a sports commentator. In the first scene, the girl is shown to be dreaming and thinking about becoming a commentator and having a fairer look. She seems to be so enthusiastic and passionate about this profession that she is shown doing commentary while standing at her balcony and watching the street children who are playing cricket. In the next scene, while she is watching television, she is shown holding something as a mike and doing commentary. A girl (may be a friend or a sister) enters and replaces the item used as a mike with the product (See Figs. 18 \&19).

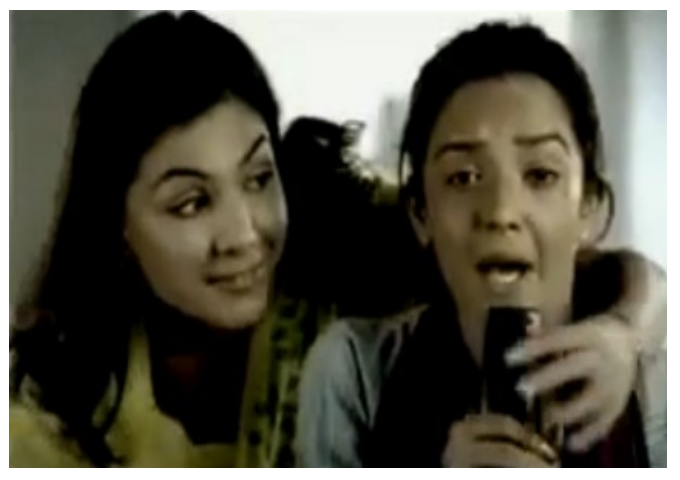

Fig. 18

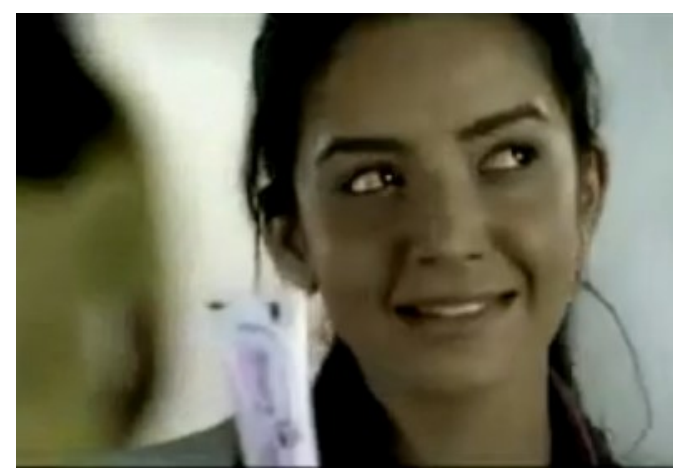

Fig. 19

After using the product, she becomes fair and beautiful and is selected for the post of a commentator. In the next scene, she is shown to be sitting next to a famous male commentator who is watching her with admiration. When she becomes a commentator, her family is shown to be happy and emotional on her achievement. In the end, she is shown giving autographs to her fans and enjoying her profession.

This ad is celebrating a woman's new role in a patriarchal society which contradicts the perceived gender roles. The profession that the girl has chosen in this ad is usually not meant for women in traditional societies like India and Pakistan. If we trace back the history of sports in Pakistan, we will find not as much women's participation as compared to men. The reason behind this fact is that it is not considered appropriate for women to be involved in such physical activities in which their body parts become 
prominent. In a typical patriarchal society, the real place of women is considered to be at home and no involvement in sports is expected from them. But the current changing times have influenced the domain of sports as well and now women are participating more actively in sports. Now Pakistani women are participating in swimming, hockey, cricket etc. In terms of female cricket commentators, Leena Moin Aziz is the first Pakistani female commentator. This ad is a fine example of progressive thoughts in this regard. Following snapshots from the ad depict a woman's new role:

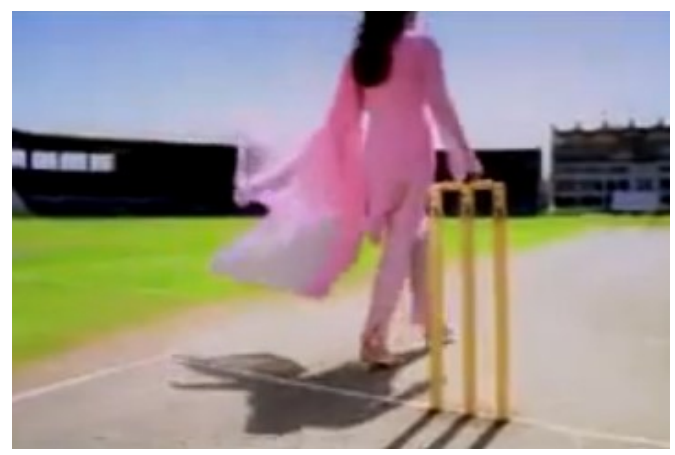

Fig. 20

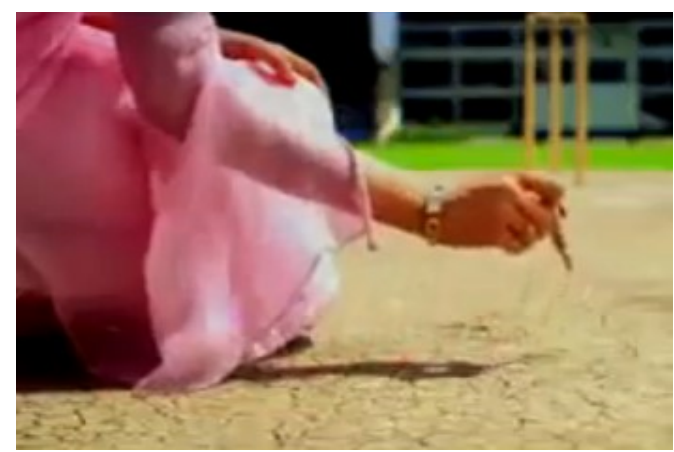

Fig. 21

It is interesting to note that although the woman is depicted as taking a new gender role, this progressive idea is combined with her beauty. The message that is conveyed is that only if she uses the product and becomes beautiful, then she will get a chance in her professional life. Another instance which is quite interesting to note is that the person who approves her as a commentator is again a male. The gender differences are obvious here as a woman always needs a man to move forward in life but a man may not necessarily need a woman to proceed professionally or socially.

In the end of the ad, immediately after the image of the girl in the cricket ground, a voiceover with the image of product on the screen states:

- Fairness cream zindagi roshan kare

(Translation: Fairness Cream makes life bright.)

This voiceover reiterates that no matter how successful a woman is in her professional life, at the end of the day she is a WOMAN who needs to look beautiful in order to be approved of socially. 


\section{Conclusions}

In the traditional context of Pakistan gender ideologies are pre conceived and certain human rights are denied to a particular gender. The same patriarchal framework also operates in Pakistani media. However, recently these gender ideologies are challenged and reconstructed. As far as Pakistani television advertisements are concerned, now-adays we can notice that advertisements related to various domains present a (seemingly) progressive view of female gender. However, a keen examination shows that most of the times it is only superficial. Analysis of the data of selected advertisements shows that these advertisements seem to present a progressive image of women but the analysis of linguistic and semiotic choices makes it clear that the advertisement makers are conscious of the social acceptability of these advertisements. In the current research selected advertisements taken from diverse domains show that new gender ideologies are presented implicitly. In the form of gender stereotypicality gender construct bars the human construct; and in presenting these gender ideologies women and men are often perceived as gendered beings instead of human beings. As a result of the analysis the question also arises whether it is reconstruction of gender ideologies or reconstruction of representation of gender ideologies; and what are the repercussions of this phenomenon.

\section{End Notes}

1. All the figures/ pictures used in the research are snapshots from the selected advertisements.

2. The abbreviated form Ad is used for advertisements.

3. Translation: Mama is slightly unwell ... today let us make breakfast for her?

4. Nano means maternal grandmother, chachi and phopho both are paternal aunties (respectively father's younger brother's wife and father's sister).

\section{References}

Arat, Z. F. (2000). Women's Rights in Islam: Revisiting Quranic Right. In A. Pollis., \& P. Schwab (Eds.). Human Rights: New Perspectives, New Realities. London: Lynne Reinner Publishers.

Barthel, D. (1988). Putting on Appearances: Ggender and Advertising. USA: Temple University Press.

Buckingham, D. \& Bragg.S. (2004). Young People, Sex and the Media the Facts of Life? New York: Palgrave Macmillan.

Cambridge Advanced Learner's Dictionary (2008). Cambridge: Cambridge University Press. 
Chafai, H. (2007). Gender and the Language of Advertising: a Sociolinguistic Analysis of Women's Representation in British and Moroccan magazine advertisements. Retrieved April 25, 2012 from http://repositorium.sdum.uminho.pt/handle/ $\underline{1822 / 7921}$

Connell, R. (2009). Gender. Cambridge: Polity Press.

Croteau, D. \& Hoynes, W. (2000). Media Society Industries, Images, and Audiences (2nd ed.). Thousand Oaks: Pine Forge Press.

Donnelly, J. (2003). Universal Human Rights in Theory and Practice. USA: Cornell University.

Fairclough, N. (1995). Media Discourse. New York: St Martins Press.

Fenster, T. (1999). Gender and Human Rights: Implications for Planning and Development. In T. Fenster (Ed.). Gender, Planning, and Human Rights. London: Routledge.

Fowles, J. (1996). Advertising and Popular Culture. Thousand Oaks: Sage.

Goldstein, J. S. (2001). War and Gender: How Gender Shapes the War System and Vice Versa. Cambridge: Cambridge University press.

Griffin, J. (2008). On Human Rights. Oxford: Oxford University press.

Hermes, J. (2007). Media Representations of Social Structure: Gender. In E. Devereux, (Ed.) Media Studies- Key Issues and Debates, Australia: Sage Publications Ltd, pp, 191-210.

Kellner, D. (1995). Cultural Studies, Multiculturalism and Media Culture. In G. Dines, \& J.M. Humez, (Eds.) Gender, Race and Class in Media- a Text Reader. Thousand Oaks: Sage.

Kessler, S.J. \& McKenna, W. (1978). Gender: An Ethno Methodological Approach. Chicago: The University of Chicago Press.

Lemish, D. (2010). Screening Gender on Children's Television- The Views of Producers Around the World. London: Rout ledge.

Messaris, P. (1997). Visual Persuasion. The Role of Images in Advertising. Thousand Oaks: Sage. 
218 Media Discourse and Gender: Issues of Reconstruction of Gender Ideologies in Pakistani Television Advertisements

Orend, B. (2002). Human Rights: Concept and Context. Canada: Broadview Press Ltd.

O’Shaughnessy, M. \& Stadler, J. (2002). Media and Society: An Introduction (2 ${ }^{\text {nd }}$ ed). Australia: Oxford University Press.

Ralhan, S.S. \& Lambat, S.R. (2007). Introduction to Sociology. New Delhi: Common Wealth Publishers

Rose, S.O. (2010). What is Gender History? Cambridge: Polity press.

Tischler, H. L. (2011). Introduction to Sociology. USA: CENGAGE Learning.

Dr. Sarwet Rasool is Assistant Professor/ In-charge Department of English, Fatima Jinnah Women University, Rawalpindi. 